\section{Bouquets and brickbat}

I find English Today to be a magazine that conforms exactly to my idea of fulfilling-a-need in the field of language study. Congratulations on your fine new publication.

- Professor Dwight Bolinger, Palo Alto, California

I want to congratulate you on the first two numbers of English Today. I think this is the best publication of its kind which has come my way in a very long experience of teaching and organising courses on English as a second language. It certainly supplies a need at a time when the question of English as a world language is becoming increasingly important, and I hope that you will continue successfully for a long time.

- Professor Raymond Chapman, London School of Economics and Political Science, University of London

It looks as if English Today will prove a very useful venture, and I particularly like your editorial hope for a publication which will appeal to both amateurs and professionals concerned with English.

○ John Edwards, St Francis Xavier University, Nova Scotia, Canada

I have gone through the first two issues and found them very interesting and educational. I admire your concern and concept of a whole new English speaking world, and also like the catholicity of selection - a marvellously refreshingly new approach.

o Balwant Naik, Teacher of English, London Borough of Ealing

I recently received my copy of the maiden issue of English Today. It's an impressive beginning. Congratulations on a job well done!

o Ron Eckart, Book Review Editor, TESOL Newsletter, Western Kentucky University, USA

I like the magazine style with photos and illustrations and variations in layout: it's contemporary and eyecatching without being slick. You have also done a fine job varying the length, topics, and technicality of the pieces. Surely any educated reader would find something appealing in ET1.

Three weeks ago I attended the annual conference of the Southeastern Conference on Linguistics, a professional association of about two hundred members who teach linguistics of some sort (usually applied) in colleges and universities in the southern part of the USA. I was amazed at how many people there had seen ET1. Their comments were all complimentary. I hope that you and the people who work so hard on the idea and the reality of English Today are pleased with its reception. I add my congratulations to the many others you have undoubtedly received.

- Connie C Eble, University of North Carolina at Chapel Hill, USA

I wish to cancel my subscription to English Today after the introductory offer runs out. My reasons are that I find review inadequate and disappointing. In fact, I find it depressingly second-rate - all the moreso since it stems from so fine a publishing house. In detail: The articles 'An ABC of World English' seem to set the style of the publication and I find them condescending, glib and vapid. Had they one tenth the wit, style and pace of, say a Phillip Howard, or even an Auberon Waugh, they might just escape from being as tedious as they are.

In Senator Mondale's phrase: 'Where's the meat?' The disturbing question raised after two issues is whether the academics and pundits writing for the magazine actually have anything to say. If they have, why don't they say it? The articles published so far seem to be packed with anything but fact and information. They are waffle - red-brick university waffle and their purpose seems to be selfadvertisement. I welcomed the introduction of this review and looked forward eagerly to its publication. I am still convinced that if it were better done it could serve a useful purpose. But I feel that you need a professional editor and some literary talent among your contributors before you can hope to achieve success.

o Franklyn T Wood, Holland on Sea, Essex, England

\section{The plupluperfect?}

Please comment - however briefly - on the proliferation of the use of the plupluperfect tense (I cannot think what else to call it). An example is: 'If he had have gone ...', almost invariably contracted to 'If he had've gone...' The latest transgressor among people who should know better is $\mathrm{Mr}$ Jim Prior [the Conservative politician] who, on BBC's Radio Four Any Questions?' (3 May) said, 'If I

Readers' letters are welcomed. ET policy is to publish as representative and informative a selection as possible in each issue. Such correspondence, however, may be subject to editorial adaptation in order to make the most effective use of both the letters and the space available. had've been there . . .' I have even heard the use in Radio and Television drama and in the narrative of news bulletins, where it would by no means have been in the script, since the form is never written, only spoken.

O Ian H Watson, Haddon on the Wall, Newcastle upon Tyne, England

We are working on it. $E d$.

\section{The past and present of the} present-future

In the Post \& Mail of the April issue Mr R Dallas Brett says he finds 'the use of the present tense for the future the most irritating of all the numerous misuses of the English language.' $M y$ response to this is taken from the greatest of all English grammars, Jespersen's Modern English Grammar, Vol. IV, Sec. 2.4(1): 'The present tense may be used in speaking of some future time. This was a regular practice in Old English, even in some connexions where it would seem necessary to express the distinction between present and future.' There follows a quotation from John 14:12 which is in Latin and Anglo-Saxon, and so I cannot reproduce it here. But Jespersen's own explanation follows: 'In using the present tense in speaking of a future tense one disregards, as it were, the uncertainty always connected with prophesying, and speaks of something not indeed as really taking place now, but simply as certain.' After speaking of Middle English, Jespersen gives further examples from Shakespeare to Shaw covering, it seems to me, just about every possible and actual use of present-future, including the colloquial. I think Mr Brett would be persuaded that his taste has misled him in this matter.

○ Bert Lippman, Coram, New York, USA

\section{A journalistic misnomer?}

Come over here where the compiler of 'An ABC of World English' can't hear us. Shame on him! Why give Indian the stigma of that terrible psychosis formerly known as dementia praecox? The word Indian is no more 'schizophrenic' than the name of your editor-compiler. $E T$, of all publications, should ban this journalistic misnomer, often indeed misused for 'dualpersonality' or 'dual-standard'. Indian is an ambiguous word, a dual-meaning word, even a many-meaning or plurisignificant word: it is NOT a 'schizophrenic' word, much less a 'truly schizophrenic word'. Leave this term to the psychiatrists and other medics and to the inferior press.

○ David I Masson, Leeds, England 


\section{Numbers in Nigeria}

I welcome the publication of English Today and have asked our University Library to subscribe to it. I was interested in the article 'How Many Millions' in ET1, which lists the first and second language speakers of English in bulk figures, to note that Nigeria was not included. There has been no census in Nigeria for a number of years, I know, but guesses put the total population somewhere near 100 million people and a fair percentage of those would use English as a second language. I wonder if you have figures which for some reason. were not included in the total and if I might know them. Good luck in this important new venture.

o G D Killam, Editor, World Literature Written in English, University of Guelph, Ontario, Canada

David Crystal: There's many a glitch between disk and print. My thanks for pointing to this omission. I had it on my original list on disk, but where it went between there and the copy sent to press only the Great Word Processor knows. For the record, my figures were 90 millions for 'official' second-language speakers, based on recent population estimates, and a question mark for first-language (undoubtedly a very small figure). Estimates vary as to the 'real' use of standard (as opposed to pidgin) English in the country, with different degrees of proficiency, from 5 to $30 \mathrm{per}$ cent of the population.

\section{Brits or not?}

As you yourself are clearly well aware (ABC of World English, ET2), Scots object to being called 'English' and to the use of England meaning Britain. As a frequent visitor to France, I endlessly try to explain and encourage the use of Britain and British. Sometimes it seems like a losing battle!

However, the other day I chanced to meet some American tourists in the centre of Edinburgh. After admiring this beautiful city and its climate, they admitted to having just driven up through rain-soaked England, and then informed me that a lot of Brits were thinking of holidaying in Scotland this year! Perhaps the Scots are no longer British; perhaps independence is round the corner? Given the pejorative overtones which 'Brit' frequently has in the mouths of Australians, Americans, Canadians, et al., perhaps the Scots should be pleased that the term no longer applies to them. The wheel seems to have gone full circle: Brit (pej. $)=$ English .

- Dr Joyce A Hutchinson, Edinburgh, Scotland
A Britisher at home

Noticed that Professor Strevens used 'Britisher' on page 7 of ET2.

Hmmmmmm. Or, Hmmmmmm? Congratulations on the first two issues.

o Dr D Stevenson, Universität Essen, West Germany

\section{A helish mess}

Now let us deel with the gratest linguistic crime in western civilizasion, English speling. Yu alredy kno that our speling iz outrajusly erratic and irrasionally inconsistent. Ar yu also aware that in eech English-speeking cuntry there iz a larj persentaje ov the populasion ( $20 \%$ in Canada) that iz funcsionally illiterat. Our educasional sistems ar gud or exsellent. The problem iz English speling, which iz the sole cauz for tens ov millions ov English speekers being illiterat around the wurld. Speling reformasion and rasionalizasion iz both inevitabl and desperatly needed now.

We need tu start the internasional discussion ov speling reformasion and tu encuraje all peepul tu uze simplified speling at all times. We must not forget that current English speling iz now such a helish mess that it can not be reformed in one step; rather, several fazes wil be nesessary.

- Ted W Culp, The Simplified Spelling Society Ov Canada, Toronto, Ontario, Canada

\section{Technospeak}

As Valerie Illingworth demonstrates in 'The Language of High Technology', the computer scene is redolent with its own distinct form of jargon and with everyday words that no longer mean what they used to. In computer sales and marketing, a new buzzword-ridden language has come into existence with the specific purpose of stunning the buyer so that he is open to a quick sell.

Common hyperbolic forms include total as in 'total system concept', fast as in 'fast response time', and high as in '-resolution', '-speed' and '-technology'. It is simply not possible to define 'fast response time', for example; depending on context, it could be a millisecond or two days. 'A high degree of compatibility' could be praise or condemnation, depending on whether you might have expected less or will only settle for perfection.

On the lighter side, many computer terms have been adopted by the public and it is possible to hear people talk of 'enjoying the down-time' when they are having a break, or 'coming on-line' when they start a conversation. In the near future conversations could run like this:

'My marriage is a real giga-flop. Jim and $I$ are only on-line together on Sunday nights. There must be a compatible interface mode for two people running at our baud rate.'

'That's really bad data, Anne. One or two more headcrashes and you two could be in for a total system collapse.'

o George St. Clare, University of Qatar, Doha, Qatar

\section{It isn't sexist really, is it, love?}

Jenny Cheshire ( $E T$, January) writes about sexist overtones in the use of words like 'love' or 'ducks' when men address women. 'Ducks' of course is regional, and regional variations add a third factor to the sexist and social aspects: 'going out wi' t'lads' suggests a closeness among these 'lads', and the possibility that the evening will include some revelry. When addressing a group of (usually married) ladies as 'girls', one is introducing a similar slight element of mischief. One member of such a group might say 'come on, girls' to the rest of the group, confirming a sense of camaraderie.

The use of 'lads', not necessarily regional this time, can also imply a special relationship or attitude: for instance, a teacher would say, 'I am teaching these boys French' (contractual, formal), but 'I'm taking these lads rock-climbing' (voluntary); teachers in special schools seem more likely to speak of their charges as 'lads'. Actually, teachers' modes of address to their pupils might repay study: a male teacher will call a girl pupil 'love', but would expect a few looks if he addressed a boy thus! But then 'love' (this may be north-west England again) is a fairly usual mode of address between two people of different sexes (or between two females) in adult-toadult or adult-to-child situations, but not in child-to-adult or child-to-child situations.

- Peter Royle, Bolton, Lancashire, England

\section{Language: his and hers}

I have a unique solution to the pronoun problem discussed in Jenny Cheshire's 'A Question of Masculine Bias'. Being a man, I would say, 'Anyone who wants to write non-sexist English will need to have his wits about him.' If, however, I were a woman, I would say, 'Anyone who wants to write non-sexist English will need to have her wits about her.' Not only does this obviate the necessity of introducing awkward neologisms, but it also identifies the sex of the writer!

○ Boman Desai, Chicago, Illinois, USA 


\section{Brave new language}

It is doubly fitting that 'A Question of Masculine Bias' (ET1) should be followed by David Crystal's feature on usage and the tenacity of prescriptive sentiments. Firstly, Jenny Cheshire's account contains a number of essentially authoritarian pronouncements as to what we ought to be saying but actually don't (yet). Secondly, she appears to be unaware of the decades of struggle against Victorian-style prescriptivism waged by linguists, many teachers and millions of speakers who have voted with their tongues and pens - the kind of people for whom they following someone, for instance, may have long been standard usage, and not because of anything to do with sex or dogma.

Such misleading statements as 'grammarians have insisted since the 16th century that the masculine gender is "the more worthy gender"' do little more than promote the right background myths for a Holy War.

The old prescriptivists made much of logic, implying that correct usage as judged by this touchstone would somehow contribute to the well-being of the language and even of society in general. However, most of their energy went into preaching fiery sermons against a ragbag of supposed mistakes such as 'It wasn't me', mistakes which proved difficult to eradicate in the converted, not to mention the lower orders. What they undoubtedly left behind was a large red herring obstructing the path of free communication - and a legacy of self-righteousness, guilt and prejudice. Nor did they, as we thankfully believed for some time, die childless.

For one group of their descendants, the magic strainer through which longsuffering language is to be poured is the supposedly sociopolitical criterion of 'sexism'. 'Logic' is at it again, producing for new mistresses such curiosities as: if $\mathrm{X}$ is mentioned before $\mathrm{Y}$, then $\mathrm{X}$ has higher status than $\mathrm{Y}$. Well, do you experience a tiny rise in socio-sexual awareness each time you say girls and boys, or gentlemen and ladies? Have you heard of hundreds of successfull A A Aardvaarks?

If we are to say mother and father at least half the time, and father and mother the other half, how is this to be monitored? It would be even more difficult to check that we are using, say, each of the combinations of Ireland, Scotland, Wales and England $4.2 \%$ of the time. And what are we to make, psycholinguistically and sociopolitically, of such common orderings as forks and spoons, black and white, ducks and drakes, and Camden and Westminster?

Each of us probably has pet hates in the usage field. Personally, I can't stand references to size, and strongly suspect that a ban on these would increase my stature. I am at present $5 \mathrm{ft} 6 \frac{1}{2}$ in tall (in the old currency and on rising ground), a fact for which I hold sociopolitical forces responsible. It all goes back to the Irish Parsnip Famine, the 119th Polish Uprising and the hijacking of language by persons of above-average height, soon after the Beginning of Time. Oh, and the Bible. It follows that I am keenly interested in the interaction between language and perceptions of size - particularly from a woman's point of view.

○ Hal (Tallboy) Stuart, London, England
English at its best, now in paperback

EVERYMAN'S GOOD ENGLISH GUIDE Harry Fieldhouse

Highly acclaimed when it appeared in hardback

'There is a hunger for authority. Ordinary people want to be told the 'rules' This is a sensible working guide to everyday written English:

Philip Howard. The Times E2.95

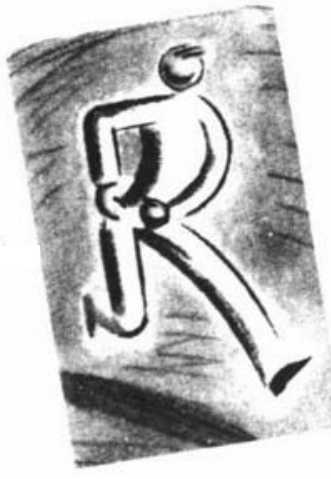

\section{PUT IT IN WRITING} John Whale

Based on the highly praised Sunday Times Magazine series

'His range of reference is impressive and his book as a whole is brisk, detailed and agreeably opinionated.'

Times Educational Supplement

'It is packed with common sense and the fruit of experience.' The Author

E2.95

in bookshops near you or direct from

Marketing Dept (Ref ET) DENT

33 Welbeck Street LONDON WIM 8LX

\section{IMPORTANT TEXTBOOKS FROM CHAMBERS}

$\widehat{N E W}$ Chambers Pocket Guide to Good English

* A concise, easy-to-use reference book of modern English usage

* Clear and simple guidelines on grammar, vocabulary, spelling, pronunciation and punctuation

* Ideal for all those who need to speak and write in English

* Self-checking hints and ways of avoiding errors

* Entries in alphabetical order, with detailed authoritative explanations

144 pages paperback $£ 1.95$ ISBN $055018029 \mathrm{X}$

\section{ESTABLISHED REFERENCE}

\section{Chambers Universal Learners' Dictionary}

'Definitions are written in clear English ... within the range of those who have made progress with their studies.'

British Book News

'This dictionary is excellent'

Oxford Review of English Studies 928 pages 40000 references $\mathbf{5 4 0 0 0}$ usage examples hardback $£ 7.95$ ISBN 0550106324

International Students' edition paperback $\mathfrak{£ 3 . 9 5}$ ISBN 0550106340

Chambers - publishers of authoritative reference and text books

W \& R Chambers Ltd, 43/45 Annandale Street, Edinburgh EH7 4AZ, United Kingdom 
English as

a World

\section{Language}

Edited by

RICHARD W. BAILEY and MANFRED GORLACH

14 fascinating and original essays which detail the history and present use of English throughout the world. Included are studies of English in Canada, the USA, South Asia, the Caribbean, Australia and New Guinea.

‘. . an enjoyable, successful and highly useful volume.'

0521261759

$$
\text { English Today }
$$

Hard covers $\$ 19.50$ net

(Available in the USA and Canada from Michigan University Press)

In case of difficulty, books can be ordered directly from Cambridge University Press.

\section{CAMBRIDGE}

\section{UNIVERSITY PRESS}

The Edinburgh Building, Shaftesbury

Road, Cambridge CB2 2RU, UK

32 East 57 th Street, New York,

NY 10022

\section{The Society of Authors}

* THE Society has over 3000 members, representative of all the media. It exists to protect authors rights. and runs specialist groups such as:

- Medical and Educational Writers

- Translators and Technical Writers

- Broadcasters and Children's Writers

* GIVES individual advice to members on any business matter connected with authorship (e.g. publishing contracts, copyright, public lending right etc.)

* TAKES up complaints on member's behalf and institutes legal proceedings when issues of general concern to the profession are at stake

* SENDS to members free of charge the Society's quarterly journal, The Author - an unrivalled source of information for writers

* PUBLISHES guides on A uthor's Agents. Copyright, Income Tax, Publishing Contracts, VAT etc.

* PURSUES campaigns on behalf of the profession (e.g. PLR, improved publishing contracts, changes in copyright legislation, returns from photocopying etc.)

* GIVES members access to the Retirement Benefit Scheme, group medical insurance and other fringe benefits

* INVITES members to business meetings and social occasions

* ADMINISTERS trust funds and awards for the benefit of authors The Society of Authors serves the interests of all who write ....

For a Booklet and further information please contact:-

THE SOCIETY OF AUTHORS,

84 DRAYTON GARDENS, LONDON SW10 9SB

\section{The Barnhart}

\section{DICTIONARY COMPANION}

The ONLY quarterly devoted to updating general dictionaries!

800 new words and meanings annually

plus book reviews special articles free binder

\section{SEND FOR A FREE SAMPLE!}

Published Quarterly

Available from:

I. LEXIK HOUSE Publishers

publisher of The Dictionary of BAHAMIAN ENGLISH
Accutane

$\mathrm{ACH}$

acroname

aerobicize

affinity charter

afterburst

age retardant

airport hug

a la pointe

al macho

amblypygid

Amerikeit

aminoglycoside

anti-holdup

antitakeover

architect

architecture

autodetermination

Autoprocess system

AVM

ayatollah or Ayatollah

Baby Doe

Baby Jane Doe

Bacon or BACON

ball: bowl with one and the same ball bare-bone it

barn burner or barn-burner or

barnburner

barrel: stare down the barrel

bear hug

bib

Big C

binary tree

biobehavioral

biobehavioral science

biomarker

bird cage

black book

black knigh

boardsailing or board sailing

boardsailor or board sailor

bonsela

bonsella

boutique

boys on the bus or boys-on-the-bus bulletin board or bulletinboard or

bultetin-board

bully pulpit

bum out

bumout or bum-out 